Tropical Journal of Pharmaceutical Research October 2019; 18 (10): 2057-2065

ISSN: $1596-5996$ (print); 1596-9827 (electronic)

(C) Pharmacotherapy Group, Faculty of Pharmacy, University of Benin, Benin City, 300001 Nigeria.

\title{
Anticancer effect of the fruit and seed extracts of Momordica charantia L. (Cucurbitaceae) on human cancer cell lines
}

\author{
Hatice Güneş ${ }^{1 \star}$, Mehlika Alper ${ }^{2}$, Nevin Çelikoğlu ${ }^{1}$ \\ ${ }^{1}$ Department of Biology, Molecular Biology and Biotechnology Division, ${ }^{2}$ Department of Molecular Biology and Genetics, Muğla \\ Sıtkı Koçman University, Muğla, Turkey
}

*For correspondence: Email: haticegunes@mu.edu.tr; Tel: +90252 2111530

\begin{abstract}
Purpose: To investigate anticancer effects of Momordica charantia L. (M. charantia) fruit and seed extracts on some cancer cell lines.

Methods: Human cancer cell lines, including lung cancer (A549), breast cancer (MCF-7), chronic myeloid leukemia (K562) and T cell leukemia (Jurkat) were incubated with the extracts ( $0-0.8 \mathrm{mg} / \mathrm{mL}$ ) for $72 \mathrm{~h}$. The cytotoxic effects of the extracts were determined using 3-(4,5-dimethylthiazol-2-yl)-2,5dipenyltetrazolium bromide (MTT) assay. A549 and MCF-7 cells were treated with the ethanol fruit extract (FE) for $24 h$ and stained with propidium iodide (PI) for the analysis of cell cycle arrest using flow cytometry. Annexin V-FITC/PI staining along with flow cytometry analysis and caspase-3 assays were carried out to determine the apoptosis of the cells treated with FE extract for $24 \mathrm{~h}$. Vascular endothelial growth factor (VEGF) secretion of the cells exposed to FE extract for $1 \mathrm{~h}$ was determined using enzyme-linked immunosorbent assay (ELISA). Cell invasion assay was applied to detect cell migration after treatment with FE extract for $48 \mathrm{~h}$.

Results: Ethanol fruit extract (FE) resulted in 90, 92, 85 and $87 \%$ cytotoxicity against K562, A549, MCF-7 and Jurkat cell lines, respectively. However, ethanol seed extract of seed (SE) was less effective ( $\leq 42 \%)$ on cytotoxicity against cancer cells. Acetone fruit extract (FA) caused 82, 75 and $59 \%$ cytotoxicity on MCF-7, Jurkat and K562 cells, respectively, whereas $20 \%$ cytotoxicity was observed on A549 cells. Dose analyses of FE extract indicated that K562 cells had the lowest IC50 value 0.082 $\mathrm{mg} / \mathrm{mL}$ ). In addition, FE extract treatment caused accumulation of A549 and MCF-7 cells in the S phase of the cell cycle. Moreover, apoptotic cell death was observed in A549 or MCF-7 cells treated with the FE extract. While the treatment of A549 cells with LPS for $24 \mathrm{~h}$ resulted in 19-fold increase in VEGF secretion, combination of FE with LPS caused 9.6-fold decrease in VEGF secretion, indicating the antiangiogenic activity of FE extract. Furthermore, FE extract treatment led to a significant decrease in the invasive properties of $A 549$ and $P C-3$ cells when compared to untreated cells.

Conclusion: Among the M. charantia extracts, FE extract displayed the highest anticancer potency against cancer cell lines, indicating that M. charantia FE extract may be a potential source for development of anticancer compounds in future.
\end{abstract}

Keywords: Momordica charantia, Anticancer, Cytotoxicity, Apoptosis, VEGF, Cell invasion

This is an Open Access article that uses a fund-ing model which does not charge readers or their institutions for access and distributed under the terms of the Creative Commons Attribution License (http://creativecommons.org/licenses/by/4.0) and the Budapest Open Access Initiative (http://www.budapestopenaccessinitiative.org/read), which permit unrestricted use, distribution, and reproduction in any medium, provided the original work is properly credited.

Tropical Journal of Pharmaceutical Research is indexed by Science Citation Index (SciSearch), Scopus, International Pharmaceutical Abstract, Chemical Abstracts, Embase, Index Copernicus, EBSCO, African Index Medicus, JournalSeek, Journal Citation Reports/Science Edition, Directory of Open Access Journals (DOAJ), African Journal Online, Bioline International, Open-J-Gate and Pharmacy Abstracts 


\section{INTRODUCTION}

Cancer is a malignant disease and it is one of the main reasons of death worldwide. External and internal factors contribute to initiate the disease. Even though tremendous progress has been made to improve chemotherapeutic anticancer agents, most of them have severe toxic side effects. Due to their lack of selectivity against cancer cells, many anticancer agents exhibit narrow therapeutic potency [1]. Therefore, substantial research has been carried out the world over to discover new anticancer agents that selectively kill malignant tumor cells but not normal cells. Plants are good sources for development of both effective and safe drugs against cancer. In fact, plants have been used as a remedy in cancer treatment for centuries cancer and more than 3000 plant species have been listed [2].

Momordica charantia L. is a bitter melon and it belongs to Cucurbitaceae family and it is known as bitter melon, karele and pare. It grows in tropical areas of the Amazon, Asia, Middle East, India and South America. This plant has long been used as both food and medicine [3]. In traditional medicine, different parts of the plant including seeds, fruits, leaves and roots have been used for treatments of microbial infections, wounds inflammation, fever and hypertension [4]. In clinical practice, $M$. charantia extracts from fruits have been used for diabetes, dyslipidemia and microbial infections [5-7].

Momordica charantia contains biologically active phytochemicals including momordin, charantin, triterpenes, proteins, steroids, alkaloids, saponins, flavonoids, fatty acids and vitamins such as A, E, C, $B_{12}$ and folic acid [8]. The blood sugar lowering property of bitter melon is due to chemicals known as charantins, insulin-like peptide and alkaloids. Several proteins in bitter melon have been identified as anticancer substances. For example, momordin was shown to have anticancer activity against Hodgkin's lymphoma in animal models. Additionally, $\alpha$ and $\beta$ momorcharin and cucurbitacin $B$ exhibit anticancer effects. Indeed, an analog of these proteins was chemically synthesized and named as "MAP-30".

Although clinical trials have not been conducted using $M$. charantia extracts in cancer patients, in vitro studies indicated that $M$. charantia extracts exhibited antitumor activities against certain cancer cell lines [9]. Purified compounds from $M$. charantia such as cucurbitane-type triterpenoids, MAP-30 and conjugated fatty acids exerted in vitro anti-tumor activities against cancer cell lines. Additionally, several studies indicated that crude extracts of $M$. charantia are more potent than individual compounds [ 10]. However, the anticancer effects of crude $M$. charantia extracts against certain cancer cell lines have not been fully elucidated.

Therefore, this study investigates the anticancer activities of crude extracts from fruit and seed of M. charantia against A549, MCF-7, K562 and Jurkat cell lines based on cytotoxicity, cell cycle arrest, apoptosis, angiogenesis and cell invasion.

\section{EXPERIMENTAL}

\section{Preparation of $M$. charantia extracts}

The plant $M$. charantia was cultivated and harvested in the Edirne province of Turkey. The aerial parts of the plant were air-dried. Dried fruit and seed of the plant were separately ground into powder and extracted with $96 \%$ ethanol or acetone by shaking at $53-55^{\circ} \mathrm{C}$. After filtration, the solvent was removed using a rotary evaporator (IKA, RV 10, USA) at $42-43^{\circ} \mathrm{C}$. The extracts were then lyophilized and stored at -20 ${ }^{\circ} \mathrm{C}$ until being used. A stock solution was obtained by dissolving the extract in $10 \%$ DMSO. Working dilutions of the extract contained DMSO less than $1 \%$ and it showed no contribution on the experimental parameters.

\section{Cell lines and culture conditions}

Cancer cell lines A549, MCF-7, K562, normal human bronchial epithelium (BEAS-2B), normal human embryonic kidney (HEK293) were originally purchased from the American Type Culture Collection (ATCC) and kind gifts from Dr. Yusuf Baran (İzmir Institute of Technology, Turkey). Jurkat cell line (Clone E6-1 ATCC) was a kind gift from Dr. Mehtap Kılıç Eren (Adnan Menderes University, Turkey). The cells were grown in RPMI 1640 medium containing stable Lglutamine; $10 \%$ fetal bovine serum (FBS); penicillin $(100 \mathrm{U} / \mathrm{mL})$ and streptomycin sulphate (100 mg/mL) (Biochrom, Germany) at $37^{\circ} \mathrm{C}$ in a humidified incubator with $5 \% \mathrm{CO}_{2}$.

\section{Cytotoxicity assay and selectivity index}

MTT

[3-(4,5-dimethylthiazol-2-yl)-2,5dipenyltetrazolium bromide] assay was carried out to detect the cytotoxic activities of the extracts. Reduction of MTT salt by living cells indicates the function of mitochondria and cell viability [11]. Cells at a density of $2 \times 10^{4}$ cells $/ \mathrm{mL}$ were seeded in 96-well plates. Following incubation for $24 \mathrm{~h}$, the cells were treated with the extract $(0-0.8 \mathrm{mg} / \mathrm{mL})$ for $72 \mathrm{~h}$. Then, $10 \mu \mathrm{L}$ 
of MTT reagent $(5 \mathrm{mg} / \mathrm{mL})$ was added into the wells and incubated for $4 \mathrm{~h}$. After discarding the medium, $100 \mu \mathrm{L}$ DMSO was added to dissolve formazan crystals. Absorbance was measured at $540 \mathrm{~nm}$ with a spectrophotometer (Thermo Scientific, Multiskan FC, USA).

Selectivity index (SI) of a crude extract is expressed as in the previous report [12] using Eq 1.

$S I=\frac{\text { LL } 50 \text { of CENC }}{\text { LLSO of CECC }}$

where $\mathrm{LC}_{50}=$ concentration required to kill $50 \%$ of the cell population, $\mathrm{CENC}=$ crude extract in a normal cell line, $\mathrm{CECC}=$ crude extract in cancer cell line.

\section{Cell cycle analysis}

Cancer cell lines at $5 \times 10^{5}$ cells were seeded in a 6 -well plate and treated with the extracts $(0.2,0.4$ and $0.8 \mathrm{mg} / \mathrm{mL}$ ) for $24 \mathrm{~h}$ at $37^{\circ} \mathrm{C}$. Cells were washed and centrifuged at $1200 \mathrm{rpm}$ for $10 \mathrm{~min}$. Resuspended cells were fixed in absolute ethanol and kept at $-20^{\circ} \mathrm{C}$ for $48 \mathrm{~h}$. After that, cells were washed with PBS and centrifuged at $1200 \mathrm{rpm}$ for $10 \mathrm{~min}$. The cells were resuspended in $1 \mathrm{ml}$ PBS containing $0.1 \%$ Triton $X-100$ and $100 \mu \mathrm{L}$ of RNase $\mathrm{A}(200 \mu \mathrm{g} / \mathrm{mL})$ and then incubated at $37^{\circ} \mathrm{C}$ for $30 \mathrm{~min}$. After adding $100 \mu \mathrm{L}$ of PI $(1 \mathrm{mg} / \mathrm{mL})$, cells were incubated for further $15 \mathrm{~min}$ in the dark. Finally, cells were analyzed by flow cytometry (BD FACSCanto) using the ModFit LT 3.0 software.

\section{Flow cytometry assay}

Exponentially growing cells were cultured at $5 \times 10^{5}$ cells in 6-well plates (Greiner, Germany) and allowed to attach for $24 \mathrm{~h}$ at $37^{\circ} \mathrm{C}$. The cells were exposed to the extracts at $0.2,0.4$ and 0.8 $\mathrm{mg} / \mathrm{mL}$ for $24 \mathrm{~h}$. Annexin V-FITC (fluorescein isothiocyanate)/PI (propidium iodide) co-staining assay was carried out according to the manufacturer's Annexin V-FITC Apoptosis Detection Kit (eBioscience, USA) protocol.

The cells treated with plant extracts were washed with PBS, tripsinized, washed and resuspended in a binding buffer. After adding $5 \mu \mathrm{L}$ of Annexin V-FITC and $10 \mu \mathrm{l} \mathrm{PI}(20 \mu \mathrm{g} / \mathrm{mL})$ into each cell suspension, the cells were incubated for $15 \mathrm{~min}$ in the dark. After adding binding buffer $(500 \mu \mathrm{L})$, 10,000 cells for each group were analyzed by flow cytometry (BD FACSCanto A, BD Biosciences) using the BD FACSDiva software v6.13.

\section{Caspase-3 activity assay}

Caspase-3 activity assay was performed according to the instructions of manufacturer of a colorimetric assay kit (Abcam, Cambridge, UK). After treatment of cells with the plant extract at $0.8 \mathrm{mg} / \mathrm{mL}$ for $36 \mathrm{~h}$, the cells were washed, harvested, lysed and centrifuged. Total protein amount was determined by the Bradford assay [13]. Then, $200 \mu \mathrm{g}$ of protein from each sample was assayed for caspase-3 activity with a specific substrate DEVD-p-NA. Absorbance of free $p$-nitroanilide ( $p-N A)$ produced by the cleavage of the substrate by activated caspase 3 was measured at $405 \mathrm{~nm}$ in a plate reader.

\section{Determination of human VEGF}

A549 cells were cultured at $2 \times 10^{5}$ cells in a 6 well plate and incubated at $37{ }^{\circ} \mathrm{C}$ for $1 \mathrm{~h}$. Then, the cells were exposed to the plant extract at 150 $\mu \mathrm{g} / \mathrm{mL}$ and incubated for $12,24,48$ or $72 \mathrm{~h}$ at $37^{\circ} \mathrm{C}$. After centrifugation, the supernatants were collected and stored at $-20^{\circ} \mathrm{C}$. Untreated cells served as control. The concentrations of VEGF in the supernatants were determined by ELISA as described in the manufacturer's procedure for the VEGF ELISA kit (Boster Biological Technology, USA). The absorbance was measured at $450 \mathrm{~nm}$ in a plate reader. The VEGF concentrations of cell culture supernatants were calculated from a standard curve of VEGF.

\section{Cell invasion assay}

Cancer cell invasion analysis was carried out according to the protocol described in the Cell Invasion Assay Kit (Chemicon, USA). Extracellular matrix (ECM) was rehydrated by adding warm serum-free medium to the upper inserts for $1-2 \mathrm{~h}$ at room temperature. After removing the medium, $500 \mu \mathrm{L}$ of medium containing $10 \%$ FBS was added to the lower chamber. A549 cells or PC-3 cells were seeded at $3 \times 10^{5}$ cells in $300 \mu \mathrm{L}$ of serum-free medium in an invasion chamber (upper insert) and treated with the plant extract at a $150 \mu \mathrm{gg} / \mathrm{mL}$ concentration for $48 \mathrm{~h}$ at $37^{\circ} \mathrm{C}$ in a $\mathrm{CO}_{2}$ incubator. After incubation, cells were gently removed using a cotton-tipped swab. The invasive cells on the surface of lower membrane were stained by dipping the insert in the staining solution $(500 \mu \mathrm{L})$ for $20 \mathrm{~min}$. Inserts were rinsed with water, air-dried and counted in 3 randomly selected fields using an inverted microscope (Olympus, E330, Japan). The percentage of invasion $(\mathrm{Pl})$ was calculated using Eq 2.

$\mathrm{PI}=\frac{\text { MNTCOM }}{\text { MNUTCOM }} \times 100 \ldots \ldots . .(2)$ 
where MNTCOM = mean number of treated cells on the membrane, MNUTCOM = mean number of untreated cells on the membrane

\section{Statistical analysis}

Each result was presented as the mean \pm SD. The data were analyzed using GraphPad Prism 7.0 (GraphPad Software, Inc., San Diego, CA). Comparison of treatments among the groups was performed using one-way ANOVA and posthoc analysis. Significance was at $p<0.01$ and $<$ 0.0001 .

\section{RESULTS}

\section{Cytotoxicity of plant extracts}

Ethanol extract of fruit $(0.8 \mathrm{mg} / \mathrm{mL})$ caused cytotoxicity more than $80 \%$ on all cell lines that were tested (Figure 1). Acetone extract of fruit (FA) displayed $82 \%$ and $78 \%$ cytotoxicity on MCF-7 and Jurkat cell lines whereas $25 \%$ and $60 \%$ cytotoxicity were observed on A549 and K562 cells. On the other hand, both ethanol (SE) and acetone (SA) extracts of seed (SA) resulted in cytotoxicity levels of lower than $42 \%$ in all cell lines that were tested. These findings show that, unlike seed extracts, fruit ethanol extract exerted a high level of cytotoxicity on A549, MCF-7, K562 and Jurkat cell lines.

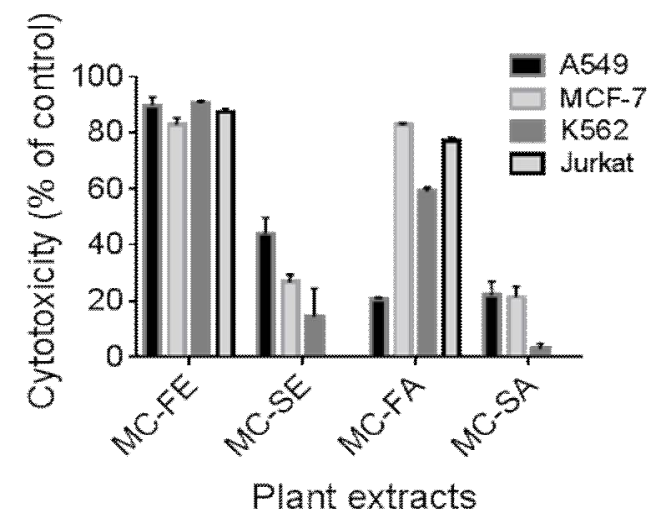

Figure 1: Cytotoxic effects of plant extracts on different cancer cell lines. Cells were treated with extracts $(0.8 \mathrm{mg} / \mathrm{mL})$ or left untreated for $72 \mathrm{~h}$. Extracts; MC, M. charantia; FE, ethanol extract of fruit; $\mathrm{SE}$, ethanol extract of seed; FA, acetone extract of fruit; SA, acetone extract of seed. Data are means $( \pm S D)$ of three independent experiments

\section{Dose- and time- dependence of cytotoxicity}

Ethanol extract of fruit (FE) exerted cytotoxic activity on A549, MCF-7 and K562 cells in a dose- and time-dependent manner (Figure 2). The percentage of cell death at all doses gradually increased for 24,48 and 72 h. A549 cells displayed $90 \%$ cytotoxicity even at 0.2 $\mathrm{mg} / \mathrm{mL}$ for $72 \mathrm{~h}$ (Figure $2 \mathrm{a}$ ), whereas MCF-cells presented 80 and $40 \%$ cytotoxicity at 0.4 and $0.2 \mathrm{mg} / \mathrm{mL}$ for $72 \mathrm{~h}$ (Figure $2 \mathrm{~b}$ ). Additionally, K562 cells exhibited $90 \%$ cytotoxicity even at 0.1 $\mathrm{mg} / \mathrm{mL}$ for $72 \mathrm{~h}$ (Figure $2 \mathrm{c}$ ). Moreover, the extract at $0.2 \mathrm{mg} / \mathrm{mL}$ caused $78 \%$ cytotoxicity on Jurkat cells (Figure $2 \mathrm{~d}$ ). According to the $\mathrm{IC}_{50}$ values, K562 was the most sensitive cell line because it had the lowest $I_{50}$ value $(0.082$ $\mathrm{mg} / \mathrm{mL}$ ) compared to the other cell lines.

One of the most important aspect of an extract is selective cytotoxicity against cancer cells compared to normal cells. Therefore, the cytotoxic effect of the FE extract was tested on normal cell lines BEAS-2B and HEK293, as well. Although the extract at $0.2 \mathrm{mg} / \mathrm{mL}$ caused $90 \%$ cytotoxicity on A549 cells at $72 \mathrm{~h}, 50 \%$ cytotoxicity was observed in BEAS-2B (Figure 2 e). In addition, HEK293 cells exhibited cytotoxicity less than $30 \%$ at all doses tested (Figure $2 \mathrm{f}$ ). These results indicate the selectivity of the FE extract against the cancer cells.
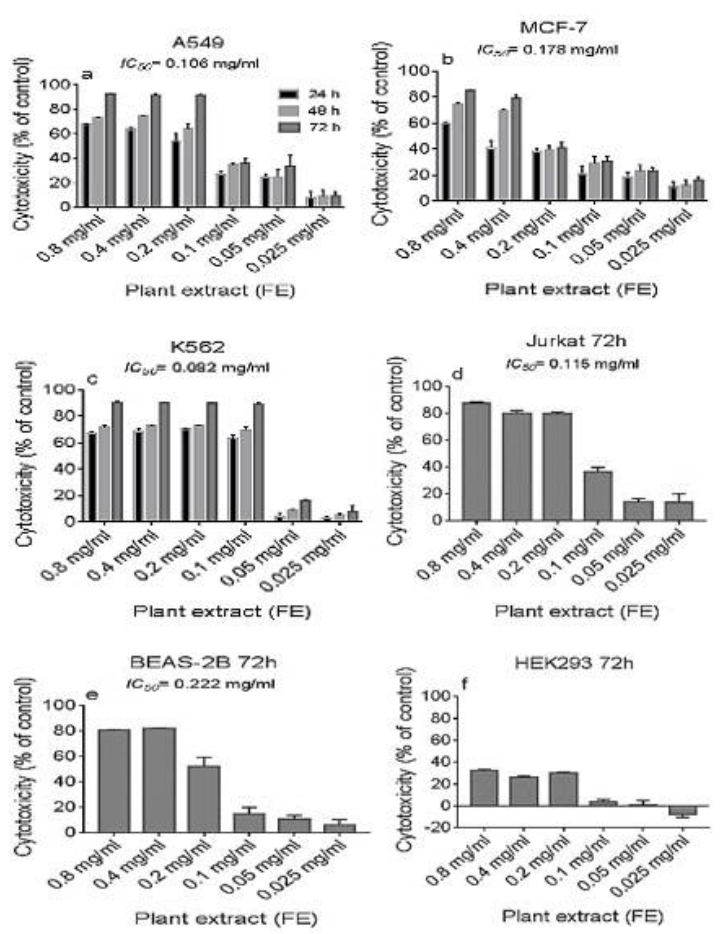

Figure 2: Dose- and time-dependent effects of FE extract

As acetone extract of fruit (FA) exerted the most effective cytotoxic effect on MCF-7 and Jurkat cells (Figure 1), time- and dose-dependent response of MCF-7 cells and dose-dependent response of Jurkat cells were tested. The highest cytotoxicity was observed after $72 \mathrm{~h}$ of incubation for all doses (Figure 3 a). While MCF-7 cells 
exhibited $80 \%$ cytotoxicity at $0.2 \mathrm{mg} / \mathrm{mL}$, Jurkat cells displayed $38 \%$ cytotoxicity at $72 \mathrm{~h}$ (Figure 3 $\mathrm{a}, \mathrm{b})$. Based on the $\mathrm{IC}_{50}$ values, MCF-7 cells were more sensitive to the extract than Jurkat cells. However, normal cell line HEK293 displayed cytotoxicity less than $30 \%$ after treatment with the FA extract at all doses (Figure $3 \mathrm{c}$ ), indicating the selectivity of the extract.

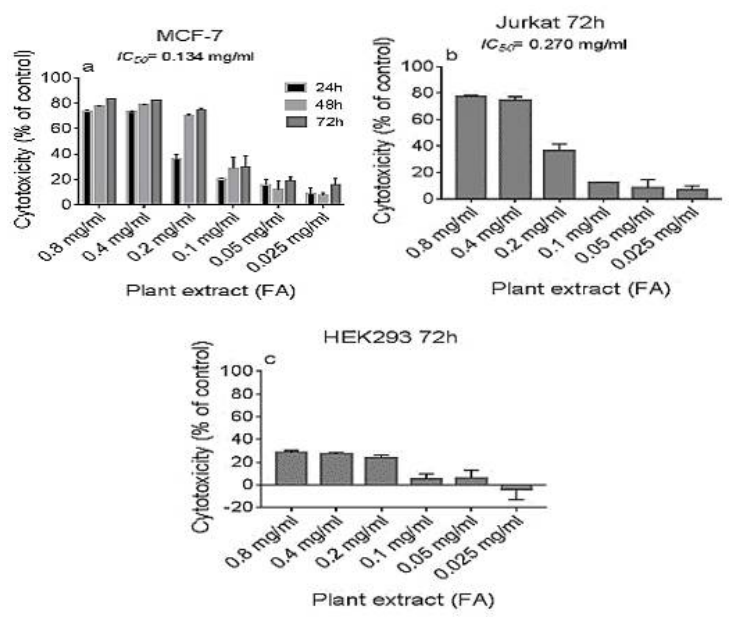

Figure 3: -Dose and time- dependent effects of FA extract

\section{Effects of FE extract on cell cycle distribution of cancer cells}

A549 and MCF-7 cells were treated with the FE extract at $0.2,0.4,0.8 \mathrm{mg} / \mathrm{mL}$ for $24 \mathrm{~h}$ to see if progression of the cells through the cell cycle was arrested. Extract at $0.2 \mathrm{mg} / \mathrm{mL}$ displayed no significant effect on the $G_{1}, S$ and $G_{2}$ phases of A549 cells in comparison to the untreated control cells (Figure 4A a,b,e). However, the extract at 0.4 and $0.8 \mathrm{mg} / \mathrm{mL}$ caused an increase in the number of cells at the S phase to 30 and $61 \%$, respectively (Figure 4A a,b,c and Figure 5 a). Additionally, the percentage of cells at the $G_{2}$ phase gradually increased in control to $18.7 \%$ in A549 cells treated with the extract at $0.4 \mathrm{mg} / \mathrm{mL}$. However, the percentage of cells was 0.4 at the $\mathrm{G}_{2}$ phase of cells treated with the extract at 0.8 $\mathrm{mg} / \mathrm{mL}$ (Figure 4A a,b,c and Figure $5 \mathrm{a}$ ). These results indicate that, when A549 cells were treated with the extract at 0.4 and $0.8 \mathrm{mg} / \mathrm{mL}$, they were arrested at the $S$ phase of the cell cycle.

The cell cycle distribution of MCF-7 cells are presented in Figure 4B. Similar to A549 cells, MCF-7 cells exhibited cell cycle arrest at the $S$ phase of the cell cycle after treatment with the extract at all concentrations that were tested (Figure 4 B, a,b,c,d, and Figure 5 b).
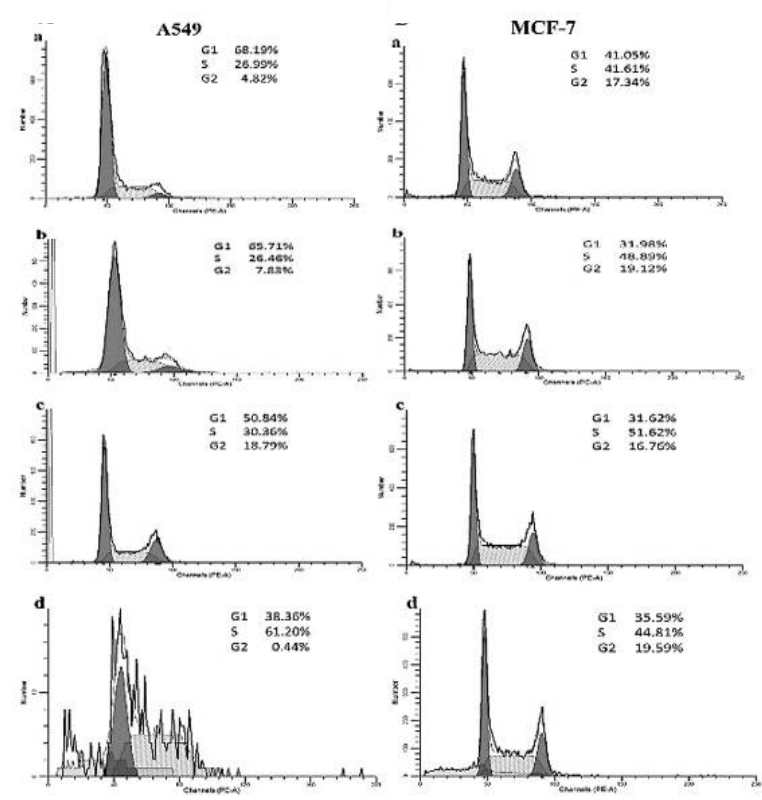

Figure 4: Cell cycle analysis of cancer cell lines treated with FE extract of $M$. charantia. Treated cells were stained with propidium iodide and DNA content was determined using flow cytometry. Histograms present cell cycle distribution of A549 (A) and MCF-7 (B) cells after treatment with no extract (a), $0.2 \mathrm{mg} / \mathrm{mL}$ extract (b), $0.4 \mathrm{mg} / \mathrm{mL}$ extract (c) $0.8 \mathrm{mg} / \mathrm{mL}$ extract for $24 \mathrm{~h}$
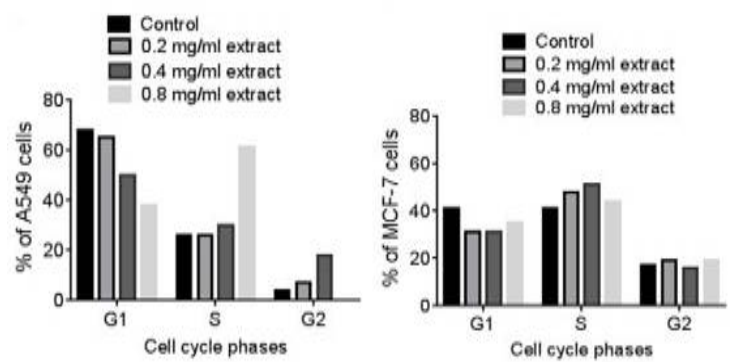

Figure 5: Proportion of cells (\%) at $\mathrm{G}_{1}, \mathrm{~S}$ and $\mathrm{G}_{2}$ phases of the cell cycle are shown in a bar diagram

\section{Effect of FE extract on apoptosis of cancer cells}

Disruption of cell cycle progression may induce apoptotic/necrotic cell death. Therefore, flow cytometric analysis was carried out to determine if apoptosis was induced in A549 and MCF-7 cells after treatment with the extract $(0.2,0.4$, and $0.8 \mathrm{mg} / \mathrm{mL}$ ). The extract at $0.2 \mathrm{mg} / \mathrm{mL}$ did not cause an increase in the percentage of apoptotic cells in comparison to the untreated cells (Figure 6A a,b, and Figure $7 \mathrm{a}$ ). On the other hand, the percentage of apoptotic A549 cells increased from $3.7 \%$ (untreated) to 6 and $39.5 \%$ after treatment with the extract at doses of 0.4 and $0.8 \mathrm{mg} / \mathrm{mL}$, respectively (Figure $6 \mathrm{~A}$ a,c,d and Figure 7 a). When the apoptotic cells were examined in MCF-7 cells, the percentage of 
apoptotic cells increased from $2 \%$ (untreated) to 19.9 and $35.5 \%$ in the cells treated with the extract at 0.4 and $0.8 \mathrm{mg} / \mathrm{ml}$, respectively (Figure $6 \mathrm{~B}$ a,c,d and Figure $7 \mathrm{~b}$ ). These results indicate that the FE extracts at doses of 0.4 and 0.8 $\mathrm{mg} / \mathrm{mL}$ promoted apoptosis in both A549 and MCF-7 cells. These findings support the data observed in cell cycle analysis, especially in the cells treated with $0.8 \mathrm{mg} / \mathrm{mL}$ extract.
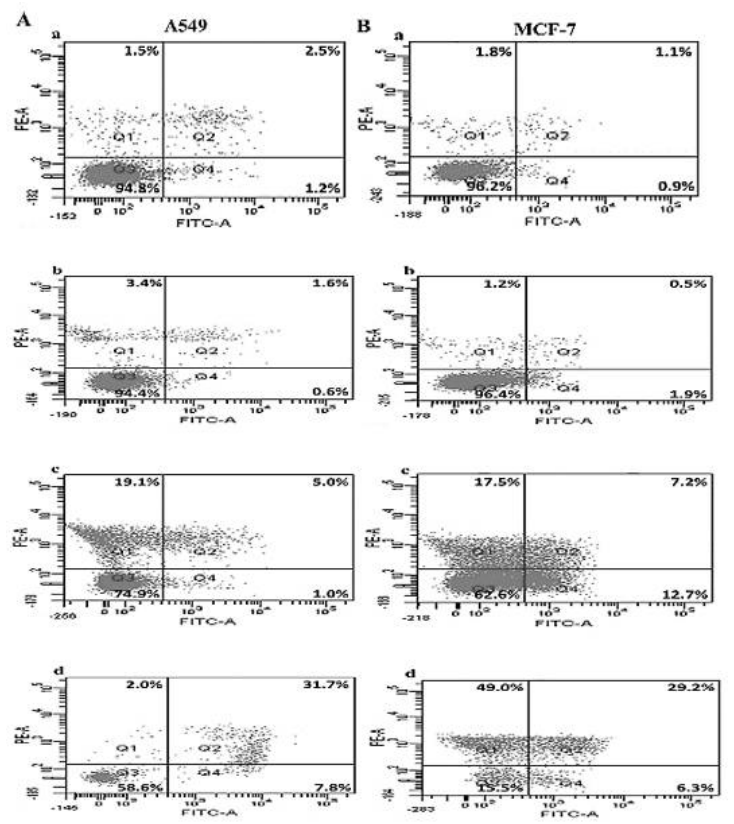

Figure 6: Flow cytometric analysis of apoptosis in cancer cells treated with FE extract. A549 (A) and MCF-7 (B) cells were treated with no extract (a), 0.2 $\mathrm{mg} / \mathrm{mL}$ (b), $0.4 \mathrm{mg} / \mathrm{mL}$ (c) and $0.8 \mathrm{mg} / \mathrm{mL}$ extract (d) for 24 h. Cells were distributed into four quadrants: viable cells (Q3), early apoptotic cells (Q4), late apoptotic cells (Q2) and necrotic cells (Q1)
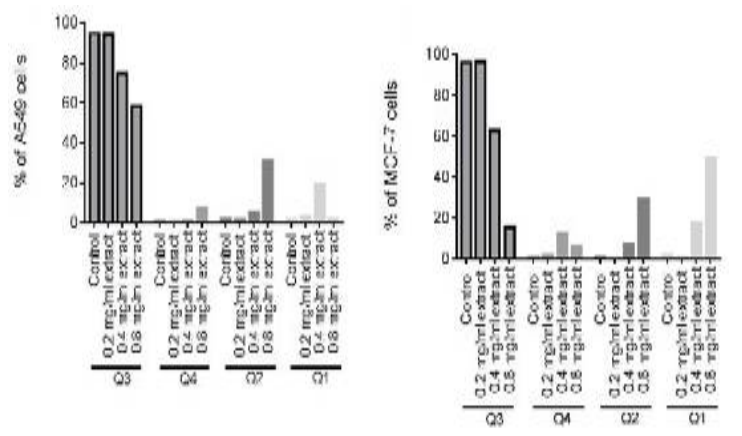

Figure 7: Percentages of apoptotic cells are presented as a bar diagram

\section{Effect of FE extract on caspase-3 activation}

Caspases involved in apoptosis are caspase-3,$6,-7,-8,-9$. Caspase- 3 is one of the caspases with roles in execution of apoptosis in a cell so that the cleavage of an apoptotic substrate by activated caspase- 3 is a good indicator of the presence of apoptosis. In this study, A549 cells were treated with the FE extract at $0.8 \mathrm{mg} / \mathrm{mL}$ for $36 \mathrm{~h}$ to see if caspase-3 was activated. The results of three independent experiments showed that the extract caused 15-fold increase in caspase-3 activity of treated A549 cells in comparison to untreated control cells $(p<0.0001)$. This result is consistent with the data obtained from the flow cytometric analysis.

\section{Effect of extracts on VEGF secretion}

Numerous phytochemical compounds from plant extracts may influence the angiogenic activity of various cell types. Airway epithelial cancer cell line A549 releases the VEGF protein constitutively [14]. Therefore, the angiogenic effect of the FE extract of $M$. charantia at 0.15 $\mathrm{mg} / \mathrm{mL}$ was examined on A549 cells. VEGF secretions of A549 cells treated with the FE extract at different time points $(12,24,48$ and 72 h) were respectively $3.6,2.8,2.1$, and 1.4-fold higher than those of untreated control cells (Figure 8). Similar results were obtained with cells treated with the FA extract. Additionally, VEGF secretion of A549 cells treated with lipopolysaccharide (LPS, $10 \mu \mathrm{g} / \mathrm{mL}$ ) for 24 and $48 \mathrm{~h}$ were 19- and 17-fold higher than those of untreated cells. However, combination of the FE extract with LPS resulted in 9.6 and 4.6-fold decrease in VEGF secretion after 24 and $48 \mathrm{~h}$ of treatment, respectively (Figure 8). These findings indicate that $M$. charantia FE and FA extracts have significant effects on induction of angiogenesis when compared to untreated A549 cells. However, the FE extract in combination with LPS resulted in a significant decrease in VEGF secretion when compared to that observed in the cells treated with LPS alone.

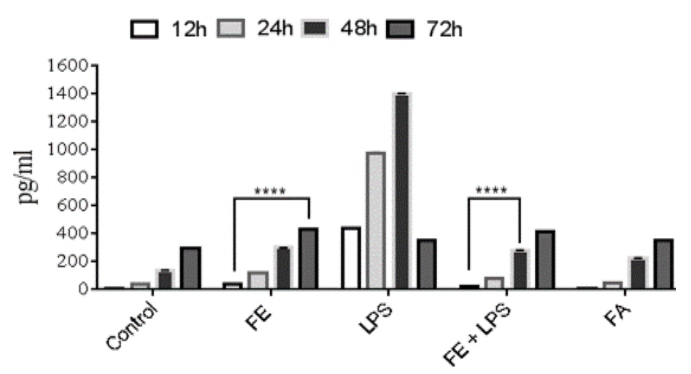

Figure 8: Effect of the extracts on VEGF secretion of A549 cells. Cells were left untreated or treated with $150 \mu \mathrm{g} / \mathrm{mL}$ extract for different time points, and VEGF concentration in supernatants was detected by ELISA. Data are mean \pm SD of triplicate samples. ${ }^{* * *} p<$ 0.0001

\section{Effect of FE extract on cell invasion}

One of the most important steps in tumor metastasis is correlated with cell invasion that 
involves cellular migration and interaction with the microenvironment. Cell invasion assay was carried out to see if $M$. charantia FE extract has an effect on invasion of cancer cells. Lung cancer A549 and prostate cancer PC-3 cells were treated with the extract at $0.1,0.2$, and 0.4 $\mathrm{mg} / \mathrm{mL}$ for $24 \mathrm{~h}$. Invasive cells passing through the membrane were counted, and percentages of invasion were determined in comparison to the control. A549 cells treated with the FE extract at $0.1,0.2$, and $0.4 \mathrm{mg} / \mathrm{mL}$ showed $1.05,1.06$ and 1.1-fold decreases in invasion in comparison to the control (Figure 9). Similar to A549 cells, PC-3 cells also exhibited 1.14, 1.13, and 1.11-fold decreases in terms of invasion. As a result, $M$. charantia FE extract displayed a significant decrease in the invasive properties of A549 and PC-3 cancer cells, compared to untreated cells.

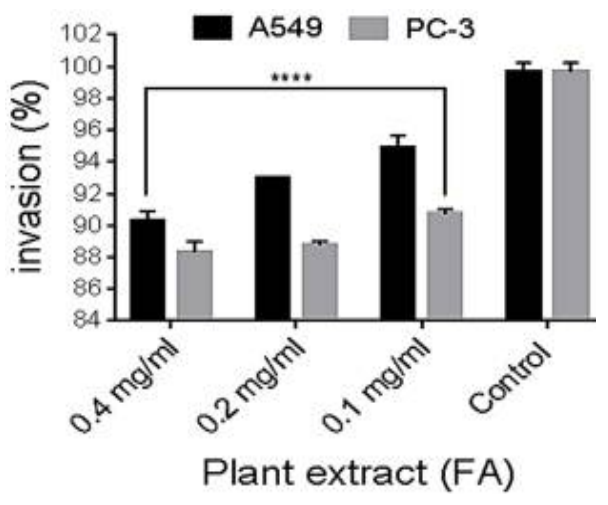

Figure 9: Effect of FE extract on invasion potential of A549 cells. Cells were treated with extract for $24 \mathrm{~h}$. Data are mean \pm SD of three independent experiments. ${ }^{* \star * *}: p<0.0001$

\section{DISCUSSION}

Extensive research had been carried out for the isolation of active components from $M$. charantia, and analysis of their pharmacological properties [15]. However, the mechanism of action of phytochemicals from this plant is poorly understood. In the light of the medicinal values of M. charantia, this study was designed to investigate its cytotoxic, apoptotic, angiogenic and invasive effects against A549, MCF-7, K562 and Jurkat cancer cell lines, as well as normal healthy cell lines BEAS-2B or HEK293.

Ethanol extract of fruit led to cytotoxicity by more than $82 \%$ on four cancer cell lines. However, the FA extract caused different levels of cytotoxicity ranging from $20 \%$ to $82 \%$ against cancer cells. Extraction of different phenolic compounds requires various solvents with differing polarities [16]. It seems that phenolic compounds extracted by ethanol are more effective on cytotoxic activity against cancer cells than those extracted by acetone. In contrast, seed extracts (SE and SA) were not as effective as fruit extracts on cytotoxic activity against the cancer cell lines. This could be due to the different kinds and levels of secondary metabolites that were present in the seed. Each part of a plant contains different secondary metabolites in different constituents [17]. Indeed, the phytochemical contents of seeds were found to be very limited when compared to the fruits [10]. Therefore, these results suggest that the fruit part of $M$. charantia should be used for development of a therapeutic agent against these cancer cells.

Development of a therapeutic drug against cancer requires selectivity between cancer cells and normal cells. If the selectivity index (SI) value of a compound is higher than 2, it is considered as high selectivity [12]. After treatment with the FE extract, A549 and K562 cells displayed $\mathrm{SI}$ values of 2 and 2.7 indicating that FE extract is more selective on K562 cells than it is on A549 cells. In contrast, the SI value of MCF-7 and Jurkat cells were 1.2 and 1.9. The fact that the greater the $\mathrm{SI}$ value is, the more selective it is and SI value less than 2 indicates general toxicity [12], it can be suggested that FE extract of $M$. charantia may be a promising therapeutic candidate in patients with lung cancer and chronic myeloid leukemia.

Cell cycle progression from the $G_{0}$ to $M$ phase is mainly regulated by cyclins and cyclin-dependent kinases (CDKs). Inhibition of cell cycle progression is an effective strategy for development of a novel cancer drug. Cell cycle analysis of the FE-treated A549 cells revealed that the FE extract induced $S$ phase cell cycle arrest at $24 \mathrm{~h}$ in this study. Similarly, another study reported cell cycle arrest at the $S$ phase after treatment with $M$. charantia extracts [18]. This indicates that the FE extract might interfere with initiation of DNA replication. Arrest at the S phase occurs through direct binding of a suppressor to replication machinery or phosphorylation of a critical element of replication control [19]. Agents that induce expression of cell cycle inhibitory regulators such as INK4 and Cip/Kip family members may be beneficial in control of malignant formations. From this finding, it appears that FE extract causes cell cycle arrest at the $S$ phase by mechanisms yet to be revealed.

Induction of the apoptotic pathway within cancer cells is a main target for development of a therapeutic drug. Apoptosis was determined using simultaneous staining of cells with FITCAnnexin-V/PI. In early apoptosis, membrane phosphatidylserine (PS) is translocated from the 
inner to the outer surface of the cytoplasmic membrane. Translocated PS may be detected and quantified using flow cytometry. In this study, dose dependent increase in early and late apoptosis suggests that induction of apoptosis takes place through more than one pathway which is probably due to many compounds in the FE extract. In addition, apoptosis was confirmed by observation of raising activity of caspase-3 in FE-treated cells. Activation of executer caspase3 can be mediated by different caspase activities [20]. Therefore, evaluation of different caspase activities in FE treated cells will reveal the pathway responsible for caspase-3 activation.

Angiogenesis is defined as formation of new blood vessels, and it plays an important role in metastatic spread of tumor cells. Vascular endothelial growth factor (VEGF) and its receptor are major mediators of angiogenesis. Lipopolysaccharide (LPS) is a strong stimulator of inflammation, and it can also lead to carcinogenesis and promotes angiogenesis [21]. After treatment of A549 cells with the FE extract, a slight increase in VEGF secretion was observed However, LPS treatment of cells led to a major elevation of VEGF levels in comparison to untreated cells. Interestingly, this elevation decreased sharply in the cells treated with LPS plus the extract, suggesting anti-angiogenic function of the FE extract of $M$. charantia in A549 cells. Similarly, $\mathrm{Xu}$ et al [22] reported that sesamin resulted in a reduction of LPS-induced invasion and VEGF secretion of PC-3 cells. Elucidation of the molecular mechanism involved in an anti-angiogenic effect may improve the potential of the extract to be used as a new therapeutic agent for treatment or prevention of lung cancer.

Malignant tumor development depends on invasive and metastatic capacity of tumor cells. In this study, the FE extract did not increase the invasive properties of A549 and PC-3 cells, but it significantly decreased invasion of the cells. Invasion and migration of cancer cells are regulated by multiple molecular mechanisms. For example, matrix metalloproteinases (MMPs) are involved in tumor invasion and metastasis [23]. Both MMP-2 and -9 play a role in degradation of type-I and type-IV collagens and the extracellular matrix (ECM). However, tissue inhibitors of metalloproteinases (TIMPs) form complexed with MMPs and prevent their proteolytic activities. Therefore, overexpression of TIMPs may prevent invasion and metastasis in several cancer cells. Future studies may elucidate possible signaling pathways involved in inhibition of MMP-2 and MMP-9 expression and stimulation of TIMP1 and
TIMP2 in A549 and PC-3 cancer cells after treatment with the FE extract of $M$. charantia.

\section{CONCLUSION}

The findings of this study show that the ethanol fruit extract of $M$. charantia has the highest cytotoxic activities of all the extracts examined (> $80 \%$ ) against A549, MCF-7, K562 and Jurkat cell lines. This extract causes cell cycle arrest at the S phase and apoptotic cell death in A549 and MCF-7 cells, as well as inhibition of invasion and LPS-induced angiogenesis of A549 and/or PC-3 cells. These findings suggest that FE extract may be a promising tool for the development of anticancer drugs against lung cancer, breast cancer, chronic myeloid leukemia and $\mathrm{T}$ cell leukemia. Future studies should attempt to elucidate the molecular mechanisms regulating the extract-mediated cellular signaling in these cancer cell lines.

\section{DECLARATIONS}

\section{Acknowledgement}

This work was supported by the grants 15/006 and 15/247 from the Scientific Research Projects (BAP), Muğla Sıtkı Koçman University. We thank Dr. Fatma Güneş from Trakya University for providing the M. charantia plant. We thank Özgür Yılmazer Okur from IYTE for her help on flow cytometry analysis.

\section{Conflict of interest}

No conflict of interest is associated with this work.

\section{Contribution of authors}

We declare that this work was carried out by the authors named in this article, and all liabilities pertaining to the claims related to the content of this article will be borne by the authors. HG designed the experiments. MA, NÇ and $H G$ performed the experiments. $\mathrm{HG}, \mathrm{MA}$ and $\mathrm{NC}$ analyzed the data. HG wrote the manuscript.

\section{Open Access}

This is an Open Access article that uses a funding model which does not charge readers or their institutions for access and distributed under the terms of the Creative Commons Attribution License (http://creativecommons.org/licenses/by/ 4.0) and the Budapest Open Access Initiative (http://www.budapestopenaccessinitiative.org/rea 
d), which permit unrestricted use, distribution, and reproduction in any medium, provided the original work is properly credited.

\section{REFERENCES}

1. Krazt F, Müller IA, Ryppa C, Warnecke A. Prodrug strategies in anticancer chemotherapy. Chem Med Chem 2008; 3: 20-53.

2. Kaur R, Kapoor K, Kaur H. Plants as a source of anticancer agents. J Nat Prod Plant Resour 2011; 1: 119-124.

3. Batran SAESE, El-Gengaihi SE, El-Shabrawy OA. Some toxicological studies of Momordica charantia, L. on albino rats in normal and alloxan diabetic rats. $J$ Ethnopharmacol 2006; 108(2): 236-242.

4. No authors listed. Momordica charantia (bitter melon). Monograph. Altern Med Rev 2007; 12(4): 360-363.

5. Oishi $Y$, Sakamoto $T$, Udagawa $H$, Taniguchi $H$, Kobayashi-Hattori K, Ozawa $Y$, Takita T. Inhibition of increases in blood glucose and serum neutral fat by Momordica charantia saponin fraction. Biosci Biotechnol Biochem 2007; 71: 735-740

6. Chaturvedi $P$, George $S$, Milinganyo $M$, Tripathi $Y B$. Effect of Momordica charantia on lipid profile and oral glucose tolerance in diabetic rats. Phytother Res 2004; 18: 954-956.

7. Mwambete $K D$. The in vitro antimicrobial activity of fruit and leaf crude extracts of Momordica charantia: a Tanzania medicinal plant. Afr Health Sci 2009; 9: 34-39.

8. Anilakumar KR, Kumar GP, Ilaiyaraja N. Nutritional, pharmacological and medicinal properties of Momordica charantia. Int J Nutr Food Sci 2015; 4: 75-83.

9. Singh RM, Cummings $E$, Patel $M$, Jeeboo $K$, Singh J. Anti-cancer properties of bioactive compounds isolated from Momordica charantia: A mini review. Advancement in Medicinal Plant Research 2016; 4(3): 83-93.

10. Manoharan G, Cummings E, Singh J. Effects of crude water-soluble extract of Momordica charantia on viability, caspase activity, cytochrome-c release and cytosolic calcium levels in different cancer cell lines. Cancer Cell Microenviron 2014; 1(e273): 1-11.

11. Holst Hansen C; Brünner N. MTT Cell Proliferation assay, Cell Biology: A Laboratory Handbook. San Diego Academic Press; 1998. p. 16-18.
12. Badisa RB, Darling-Reed SF, Joseph $P$, Cooperwood JS, Latinwo LM, Goodman CB. Selective cytotoxic activities of two novel synthetic drugs on human breast carcinoma MCF-7 cells. Anticancer Res.2009; 29:2993-2996

13. Bradford MM. A rapid and sensitive method for the quantitation of microgram quantities of protein utilizing the principle of protein-dye binding. Anal Biochem 1976; 72: 248-254.

14. Koyama S, Sato E, Tsukadaira A, Haniuda M, Numanami H, Kurai M, Nagai S, Izumi T. Vascular endothelial growth factor mRNA and protein expression in airway epithelial cell lines in vitro. Eur Respir J 2002; 20: 14491456.

15. Tcheghebe OT, Timoléon M, Seukep AJ, Tatong FN. Ethnobotanical uses, phytochemical and pharmacological profiles, and cultural value of Momordica charantia Linn.: An overview. J Med Plant Res 2016; 4(4): 23-39.

16. Wong PYY, Kitts DD. Studies on the dual antioxidant and antibacterial properties of parsley (petroselinum crispum) and cilantro (coriandrum sativum) extracts. Food Chem 2006; 97: 505-515.

17. Fletcher JC. Coordination of cell proliferation and cell fate decisions in the angiosperm shoot apical meristem. BioEssays 2002; 24(1): 27-37.

18. $R u$, Steele $R$, Nerurkar $P V$, Phillips $N$, Ray RB. Bitter melon extract impairs prostate cancer cell cycle progression and delays prostatic intraepithelial neoplasia in TRAMP model. Cancer Prev Res (Phila) 2011; 4(12): 2122-2130.

19. F Borel, FB Lacroix, and RL Margolis. "Prolonged arrest of mammalian cells at the G1/S boundary results in permanent $S$ phase stasis. Journal of Cell Science 2002;115(14): 2829-2838.

20. Soung $\mathrm{YH}$, Jeong EG, Ahn CH, Kim SS, Song SY, Yoo NJ, Lee SH. Mutational analysis of caspase 1, 4, and 5 genes in common human cancers. Human Pathology 2008;39(6):895-900.

21. Mantovani A. Cancer: inflammation by remote control. Nature 2005; 435: 752-753.

22. $X u$, Cai F, Liu X, Guo L. Sesamin inhibits lipopolysaccharide-induced proliferation and invasion through the p38-MAPK and NF-KB signaling pathways in prostate cancer cells. Oncol Rep 2015; 33: 3117-3123.

23. Deryugina El, Quigley JP. Matrix metalloproteinases and tumor metastasis. Cancer Metast Rev 2006; 25: 9-34. 